Studia Anglica Posnaniensia 50/1, 2015

doi: 10.1515/stap-2015-0016

\title{
RICHARD ROLLE'S PSALTER RENDITION: THE WORK OF A LANGUAGE PURIST?
}

\author{
KINGA LIS ${ }^{*, * *}$ \\ John Paul II Catholic University of Lublin
}

\begin{abstract}
Richard Rolle's Psalter rendition, as any of the medieval English Psalter translations, is thickly enveloped in a set of assertions, originating in the nineteenth century, whose validity has been accepted unquestioned. It is the purpose of the present paper to investigate one such claim concerning the vocabulary selection, according to which Rolle's rendition would employ almost exclusively lexical items of native origin, except for the instances where no proper item with native etymology presents itself in a particular context and Rolle is forced to use a Latin-derived word. The assertion generates at least two problematic issues. Firstly, it identifies Rolle's translation as most exceptional in relation to the remaining 14th-century English Psalter translations: the Wycliffite Bibles and the Middle English Glossed Prose Psalter of which the former are asserted to be overtly influenced by the Latin text they render and the latter deeply indebted both syntactically and, more importantly, lexically to a 'French source'. Secondly, it ascribes Richard Rolle the ideas nowadays covered by the term linguistic purism. Therefore, it seems necessary to analyse the lexical layer of the text in search of evidence, or lack thereof, which sets Rolle's translation lexically apart from other renditions and sheds some light on the issue of Rolle's supposed linguistic purism. Such a study is conducted on the basis of the nominal layer of the first fifty Psalms of the four relevant texts analysed in relation to their common Latin source text as only the juxtaposition of all of these enables one to (dis)prove the claim cited above. To provide a wider context from which to view them, the findings will be presented in relation to an overview of the contemporary theory of translation and set against a broadly sketched linguistic map of contemporary England.
\end{abstract}

Keywords: Richard Rolle, Psalter, etymology, translation, loanword

Corresponding author: Kinga Lis (kinga.lis@kul.pl), Institute of English Studies, John Paul II Catholic University of Lublin, Al. Racławickie 14, 20-950 Lublin, Poland.

** I would like to thank Professor Magdalena Charzyńska-Wójcik for all her help with this paper. 


\section{Introduction}

The paper sets out to investigate one of the assertions pertaining to Richard Rolle's Psalter translation, and more precisely to its linguistic layer, phrased by Partridge (1973: 21) in the following manner:

\footnotetext{
"Rolle adhered with fidelity to the Latin original, using the simplest and most proper English wherever possible, except when his native language failed him, and he was compelled to latinize"
}

The excerpt quoted above leads the reader to deduce that Rolle's rendition would employ almost exclusively vocabulary of native origin, except for instances where no proper item with native etymology presents itself in a particular context and Rolle is forced to use a Latin-derived word. Such an interpretation, however, would amount to ascribing Richard Rolle the ideas nowadays covered by the term linguistic purism, albeit of a mild form. ${ }^{1}$ There are a number of issues inevitably entailed in this assumption. Firstly, Rolle would need to have a 'linguistic' knowledge extensive enough to enable him to differentiate between lexical items on the basis of their etymology. Secondly, it would take an extremely disciplined and individualistic translator, if one takes into account also other (nearly) contemporaneous Psalter renditions, allegedly replete with loanwords, to incorporate such an endeavour into the task of Bible translation, especially if Rolle's primary focus was providing as close a rendition of the original as possible (Bramley 1884: 3-5). Thirdly, he would need to be exceptional or even isolated in his linguistic views since the Middle English period was a time when not only the term linguistic purism, an 18th-century French coinage (McArthur 1992: 827), would sound foreign. It seems that its denotatum itself would not be understood, let alone met with acceptance in the contemporary society of the time (cf. Section 3 ). In fact, such an attitude to language would be first observed in England only in the 16th century, i.e., two centuries after Rolle completed his rendition (McArthur 1992: 827).

Interestingly, Partridge (1973: 21) presents no evidence to corroborate his claim and since the assertion itself - old as it is - has never been either confirmed or openly rejected, I undertook to address this issue. Admittedly, Rolle's linguistic convictions would be impossible to gauge in a straightforward manner, which is why one needs to establish a point of reference from which to measure Rolle's alleged linguistic purism and more accurately his faithfulness to the vocabulary of native provenance. Therefore, I decided to analyse the text

As stated in McArthur (1992: 827), purism, when applied to vocabulary, usually manifests itself, among other things, in dispensing with borrowings, even at the cost of coining neologisms. 
while juxtaposing it with the remaining 14th-century prose Psalter renditions in relation to which Rolle's translation would be identified, if Partridge's (1973: 21) claim were correct, as most exceptional. The translations in question are the Wycliffite Bibles and the Middle English Glossed Prose Psalter, of which the former are asserted to be overtly influenced by the Latin text they render (Condit 1882: 64-73, Delisle and Woodsworth 1995: 32, Norton 2000: 7, Daniell 2003: 76-80) and the latter is considered to be deeply indebted both syntactically and, more importantly, lexically to a 'French source' (Reuter 1938).

As a result, the paper aims to analyse the lexical layer of the text in search of the evidence, or lack thereof, which sets Rolle's translation lexically apart from the other renditions. Such a study is to be conducted on the basis of the nominal layer of the first fifty Psalms of the four relevant texts, scrutinised in relation to their common Latin source text, as only the juxtaposition of all of these enables one to (dis)prove the claim cited above.

The structure of the paper is the following. Succinct information regarding each of the texts employed in the research is presented in Section 2. This is followed by an overview of the contemporary theory of translation set against a broadly sketched linguistic map of contemporary England (Section 3), as these are indispensable if one aims at providing a wider context from which to view the data. Section 4 expounds the methodology employed in the study, whereas the analysis of and concise commentary on the data proper are provided in Section 5. Section 6 presents the conclusions gathered in the course of the analysis and supplies an answer as to the validity of Partridge's (1973: 21) assertion, along with a tentative suggestion as to its source.

\section{The texts}

As stated in the Introduction, Richard Rolle's rendition (henceforth RRP) is to be discussed in relation to three other English Psalter translations: the Middle English Glossed Prose Psalter (hereafter MEGPP) and the Psalters of the Early and the Late Wycliffite Bibles (EV and LV respectively). The choice of the texts was not random and was determined by the fact that these are contemporaneous Middle English prose Psalter translations. All the four texts originated in 14th-century England, with the former two having been completed in the first and the latter two in the second half of the century. Each of them is briefly discussed below.

\subsection{Richard Rolle's Psalter}

Produced in the first half of the 14th century by Richard Rolle, this is the only translation of the four whose authorship is known. It enjoyed relative popularity with the contemporaries (Deanesly 1920, Shepherd 1969), which can be par- 
tially accounted for by the fact that "[f]or nearly two hundred years [it] was the only authorised translation of the Bible into English; it did not need diocesan permission for its use" ${ }^{2}$ (Allen 1988: 66; cf. also Daniell 2003: 69).

Such a 'privileged' position of RRP arose out of the unfavourable circumstances surrounding the Wycliffite translation(s). At the beginning of the 15th century both the Wycliffite rendition(s) and all the biblical translations into vernacular that would follow them without having obtained prior consent were declared illicit. The prohibition did not, however, include the renditions completed long before EV and LV's appearance, thus leaving RRP's 'reputation' intact. ${ }^{3}$ This becomes evident upon an examination of the text of Article 7 of Thomas Arundel's Constitutions ratified by the Provincial Council at St. Paul's (London) on 14th January 1408-09, quoted here after Pollard (1911: 79-80):

\footnotetext{
"Scriptura sacra non transferatur in linguam vulgarem nec translata interpretur donec rite fuerit examinata sub pena excommunicationis et nota hereseos.

Periculosa [quoque] res est, testante beato Hyeronymo, textum sacre scripture de unoinaliud ydioma transferee, eo quod in ipsis translationibus non de facili idem sensus in omnibus retinetur, prout idem beatus Hyeronymus, etsi inspiratus fuisset, se in hoc sepius fatetur errasse. Statuimus igitur et ordinamus, ut nemo deinceps textum aliquem sacre scripture auctoritate sua in linguam Anglicanam, vel aliam transferat, per viam libri vel libelli aut tractatus, nec legatur aliquis huiusmodi liber, libellus, aut tractatus iam nouiter tempore dicti lohannis Wyklyff, siue citra, compositus, aut in posterum componendus, in parte vel in toto, publice vel occulte, sub pena maioris excommunicationis, quousque per loci diocesanum, seu, si res exegerit, per concilium prouinciale ipsa translatio fuerit approbata. Qui vero contra fecerit, ut fautor heresis et erroris similiter puniatur"4
}

2 It needs to be emphasised that the use in question was strictly private, non liturgical and only as such the translation could be accepted by the Church, with the Bible in Latin being the only text employed for liturgical purposes in the pre-Reformation church (Charzyńska-Wójcik forthcoming).

3 That the date of the translation did matter is evidenced by the fact that "dates were adjusted on the manuscripts to turn an illegal copy of Wycliffe's Bible into a legal one" (CharzyńskaWójcik 2013: 85), as recounted in Hargreaves (1969: 394).

4 Pollard (1911: 80-81) translates it in the following manner: "The Holy Scripture not to be translated into the vulgar tongue, nor a translation to be expounded, until it shall have been duly examined, under pain of excommunication and the stigma of heresy.

Moreover it is a perilous thing, as the Blessed Jerome testifies, to translate the text of Holy Scripture from one idiom into another, inasmuch as in the translations themselves it is no easy matter to keep the same meaning in all cases, like as the Blessed Jerome, albeit inspired, confesses that he often went astray in this respect. We therefore enact and ordain that no one henceforth on his own authority translate any text of Holy Scripture into the English or other language, by way of a book, pamphlet, or tract, and that no book, pamphlet, or tract of this kind be read, either already recently composed in the time of the said John Wycliffe, or since then, or that may in future be composed, in part or in whole, publicly or privately, under pain of the greater excommunication, until the translation itself shall have been approved by the diocesan of the place or if need be by a provincial council. Whoever shall do the contrary to be punished in like manner as a supporter of heresy and error". 
Clearly, the prohibition did not in any respect include RRP, which allowed it to circulate unhindered in contrast to EV and LV. MEGPP, although not banned either, did not reach as wide an audience as RRP did (cf. Section 2.2).

Another issue worth attention is the fact that Rolle's name is inherently connected with mysticism, which raises the question of whether this mystical context affected Rolle's translation, most importantly for this paper, its lexical layer to any extent. The answer to this question, however, is negative. Rolle was an extremely conservative translator and approached the task with utmost care stemming from the reverence for the text he rendered and the belief that every word in it was sacred, in compliance with the contemporary attitude towards the Bible (cf. Section 3). ${ }^{5}$ And it is this strict adherence to the text that has earned RRP criticism for being overly literal: "unidiomatic and lacking in flexibility" (Wells 1916: 401-402), "a literal crib accompanied by a commentary" (Norton 2000: 5), "[the] work in its slavish adherence to the Latin original gives more the impression of a gloss than a translation, and, I venture to say, did give that impression even in the fourteenth century" (Paues 1902: 1x-lxi). That such critical views on RRP are misplaced is clear in the light of the information provided above. It was not Rolle's aim to produce a literary text. Rolle explains his motives in the Prologue to the Psalter emphasising the fact that he intended to "folow the lettere als mykyll as .[he]. may" (Bramley 1884: 4) and did not aim at producing 'a literary translation'. He assures the reader about his preoccupation with preserving the orthodoxy of the text and ascertains that the commentary is based on the approved sources. As Hargreaves (1965: 126) phrases it, "[h]is Psalter translation was designed not to stand alone but to follow the Latin verse by verse and to be accompanied by a commentary elucidating its spiritual meaning", which clearly is not compatible with a preoccupation with the rendition's stylistic qualities. ${ }^{6}$

5 The issue of Rolle's mysticism will not be pursued in this paper as not directly relevant to the problem of vocabulary selection, despite the fact that it would undeniably provide a wider context from which to look at the exceptional status of the Bible and its translations in medieval culture: the text was immune to any personal interpretations. For information about Rolle as 'England's First Great Mystic', see Riehle (2014).

6 That this is the case is well illustrated by the very structure of the Psalter. Each verse is treated individually in RRP and the entry for each consists of the following components: the Latin source text, the English literal translation and the English commentary on the verse, its elucidation. Such a verse composition caters for both aspects most relevant to the translation faithfulness to the original and the careful transmission of the intended message - but treats them disjointly, each in its respective, designated place. Below I provide a sample of such a verse:

Confitemini domino in cythara: in psalterio decem cordarum psallite illi. $\xi$ Shrifis til lord in the harpe: in psautery of ten cordis syngis til hym. $\xi$ In the harpe thai shrif that louys god whether wele or wa fall on thaim: and syngis til him in psautery of ten cordis, that is, stire zou to serue til charite, in the whilke ten comaundmentis is fulfild.

(Psalm 32, verse 2 from Bramley 1884: 114) 
K. Lis

The relation between the Latin source and the translation appears to be so closely knitted that Alford (1995: 48) perceives Richard Rolle's rendition "as an example of the continuing vitality of lectio divina ${ }^{7}$ in the later Middle Ages" and regards the shape of the translation and the commentary on the Psalms as an aid for those willing to embark upon this sort of religious practice:

\footnotetext{
"Clearly Rolle's English version of the Psalter cannot be read, and probably was not intended to be read, as a stand-alone translation. Repeatedly one is forced back to the original text. Reading of this sort is not a linear process but a constant upand-down movement, a stitching together of Latin and English. This oscillation between text and gloss is characteristic of lectio divina" (Alford 1995: 54)
}

The text of the Psalms scrutinised in the study comes originally from Bramley's (1884) edition as presented in Charzyńska-Wójcik (2013). The English translation provided in the edition in question is predominantly that of Manuscript 64 from the Library of University College, Oxford. Two other manuscripts were followed where the text was unavailable in the primary source (i.e. Manuscript 64): Manuscript 56 from the same library and the manuscript from the Bodleian Library, which was also the source of the Metrical Preface preceding Richard Rolle'e Prologue. The whole was collated with the Sidney Sussex Manuscript (Bramley 1884: v-xvii). The choice of the manuscripts on which the edition was based had two major sources of motivation, one of them being the fact that the Oxford manuscript is the one to best preserve the Northern dialect of the original (Everett 1922: 222). The other factor that could not have gone unnoticed is the fact that the text of the commentary which follows each verse represents Rolle's original commentary and is free from Wycliffite insertions present, to various degrees, in the commentaries, but not in the text, in the remaining extant manuscripts of RRP.

\subsection{Middle English Glossed Prose Psalter}

The most characteristic feature of this early 14th-century translation is the presence of glosses, both in the Latin and in the English texts, which are responsible for the bizarre discrepancies between MEGPP and other Psalter renditions.

It is a translation distinct among other Psalters due to its apparent modernity (St-Jacques 1989) and considered, in comparison with Rolle's version, to be "in every way a readable production" (Paues 1902: 1x). Despite this fact, it did not enjoy even some of the popularity RRP had (Carney 1980: xix, CharzyńskaWójcik 2013: 83), which would account for why only four manuscripts of

7 Alford (1995) defines it as "the monastic form of reading", which consisted of three activities: reading aloud or murmuring the text, meditation upon the text and committing it to memory. 
MEGPP have survived, two of which have been subjected to analysis in the course of this research, i.e. the British Library Additional Manuscript 17376 (the London manuscript, henceforth MEGPP L) and the Trinity College Dublin Manuscript 69 (the Dublin manuscript, hereafter MEGPP D). The remaining two manuscripts are the Cambridge Pepys Manuscript 2498 (Magdalene College) and the Scheide Manuscript 143 (Princeton University), the existence of which was first reported only after the publication of Bülbring's (1891) edition of the London and Dublin manuscripts, which, as presented in Charzyńska-Wójcik (2013), was the source of the texts under analysis here.

St-Jacques (1989: 138) explains the phenomenon of MEGPP's 'modernity' by the Psalter's dispensing with the Latin word-order, which he perceives to be a consequence of its close dependence upon the French text, first mentioned in connection with MEGPP by Paues (1902). It is not certain whether the Psalter was translated from French but the French Psalter did undoubtedly exert great influence upon its shape. ${ }^{8}$ Such dependence, according to Reuter (1938), is supposedly visible especially well in the number of borrowings from French. ${ }^{9}$

\subsection{Psalters of the Early and the Late Wycliffite Bibles}

The two Psalters are parts of the Early and the Late Wycliffite Bibles produced in England in the late 14th century and are frequently considered a text and its revision respectively rather than two independent translations (e.g. Hargreaves 1969). ${ }^{10}$ The name of Wycliffe is usually connected with the rendition(s), although opinions as to the authorship of the translation(s) differ widely. Nowadays it is accepted that Wycliffe was more of an instigator of the endeavour than an actual translator, hence the term 'Wycliffite'. EV is usually described as extremely literal and charged with introducing numerous Latinisms into the

8 Cf. Black \& St-Jacques (2012: 1xvi-1xix) for a list of features attributable to this French source.

$9 \quad$ As stated by St-Jacques (1989: 145-146), Reuter's detailed study needs to be approached with caution since "focusing as it does on French loan-words, [it] can also mislead the reader into believing that, to the detriment of its English elements, [MEGPP] makes use of many more French words than it actually does. If we set aside the strong French influence on word order or on the handling of certain recurring expressions or forms discussed above, we find a basically conservative text, which makes judicious use of French loan-words here and there but remains faithful to native vocabulary to much the same extent as does [RRP] an [EV]".

That the extent of the French source influence upon the vocabulary selection should be assessed in relation to the Latin and French originals and the remaining contemporary translations becomes evident in the light of the findings presented in Lis (2015), which corroborate St-Jacques' (1989: 145-146) opinion.

10 Extant manuscripts suggest that the process of translating and amending was continuous: the manuscripts contain texts of the different books of the Bible coming from various stages of the process (Daniell 2003: 81). 
English language (Condit 1882: 64-73, Delisle and Woodsworth 1995: 32, Norton 2000: 7, Daniell 2003: 76-80). The latter, however, does not seem to be the case, as shown in Lis (2014). LV was thus the preferred rendition and enjoyed greater popularity, despite both EV and LV being illicit (Pollard 1911: 79-80, quoted in Section 2.1). ${ }^{11}$ Therefore, LV should in principle be quite distinct from EV in both respects mentioned above. Yet, even though the comparison of the two texts is always in favour of LV, opinions concerning the degree of "the success of revision of EV" vary (Charzyńska-Wójcik 2013: 88).

Both EV and LV were edited in 1850 by Forshall \& Madden and their edition presented in Charzyńska-Wójcik (2013) constituted the source of the texts used for the purposes of the research.

\section{Approach to translation and the linguistic map of contemporary England}

As mentioned in Section 2.1, RRP is commonly considered to be a highly literal translation, hardly, if at all, palatable to its readers. Yet, it is a rendition which enjoyed popularity and was accepted by the Church. These two opposing characteristics seem to be irreconcilable and they certainly are perceived as such by a modern addressee. Nonetheless, when encountered in the context of medieval scriptural translation they cease to be viewed as mutually exclusive. The Bible, due to its exceptional status, was the only context in which Jerome ([395] 1997: 25) considered it inappropriate to translate sense-for-sense. In fact, biblical translation was expected to be literal as only a word-for-word rendition could preserve the sanctity of God's words and their sacred order:

11 Wycliffite Bibles fell prey to the controversy surrounding Wycliffe himself and as a result became prohibited, despite the fact that the extent of Wycliffe's involvement in the process of translation, if any, is unknown and regardless of the Psalters' actual textual content: the renditions consisted "only [of] the Bible text [...] translated into English from the Latin with obvious care, $[\ldots]$ generally free from additional matter; if there were glosses they were attempts at elucidation rather than aggression" (Daniell 2003: 66). Still further evidence supporting the claim that the reception of Wycliffite Bibles by the Church was distorted by Wycliffe's alleged involvement in their translation is provided by the material details of the surviving manuscripts. Poleg \& Light (2013: 6) note that "although Wycliffite Bibles have commonly been associated with the Lollard heresy, their manuscript culture links them, time and again, to orthodox patrons and practices".

As far as the religious controversy itself is concerned, already in 1377 Wycliffe was first summoned "to answer charges of heresy" (Daniell 2003: 72). His death in 1384 did not quench the conflict between his followers and the Church and in 1401 Act De heretico comburendo was issued which "hand[ed] the punishment of heretics to the state for burning" (Daniell 2003: 75). Lollardy spread widely from Oxford and in 1407 Archbishop Arundel convened a Provincial Council at Oxford where in 1409 a number of Constitutions targeted at the movement were adopted. This "imposition of a new and severe Church orthodoxy in 1409 was so successful as to make much of the liberty of religious thought or high creativity impossible" (Daniell 2003: 109) and shatter Oxford intellectual life (Bobrick 2001: 62). 
"The dominant theory of Biblical translation, based on Jerome's discussion of this specialized task rather than on his consideration of translation in general, accepted the principle that every word of the text was sacred: even the order of the words is a mystery, and this mystery must be preserved in translation" (Hargreaves 1965: 123)

This alone was reason enough to adhere to the source text as strictly as possible. Nevertheless, it was not the only factor responsible both for the type of attested biblical translations and for their paucity. The other source of this state of affairs was "a lack of confidence in the English language" (St-Jacques 1989: 135; cf. also Daniell 2003: 68-69), which in the contemporaries' eyes was an entirely inappropriate medium to convey the text of the Bible:

\footnotetext{
"For many centuries, a medieval counterpart of a modern educated person would have counted English as one of the highly unsatisfactory mediums. The vernacular appeared simply and totally inadequate. Its use, it would seem, could end only in a complete enfeeblement of meaning and a general abasement of values" (Shepherd 1969: 366)
}

This may be baffling in the light of the long history of biblical translations into the English language initiated already in the Old English period, and surprising when juxtaposed with the situation obtaining in contemporary France, where in the 14th century renditions of the Scriptures were not a rarity (St-Jacques 1989: 136-137). ${ }^{12}$ Why should that be so?

The answer, or at least a part of it, lies in the Norman Conquest, which in its wake, even if not directly, brought the obliteration of the past interlinguistic relations between the languages in use in England and relegated English to a position of a spoken vernacular, lower in status than Latin and AngloNorman/Anglo-French. Yet, it was the past exceptional position held by the English language that allowed Anglo-Norman to perform functions reserved in France for Latin. One of them stemmed from the long tradition of biblical translations which sanctioned the use of Anglo-Norman as a languge of Scriptures translation. In turn, these Anglo-Norman renditions opened the way for the continental varieties of French to follow suit. ${ }^{13}$

The view of the inappropriateness of English as a language of the Scriptures was challenged only in the 16th century mostly thanks to William Tyndale's translation of the Bible. Tyndale succeeded in translating the whole New Testament and half of the Old Testament, with only the New Testament and the Pentateuch published in his lifetime. He is given credit, however, not only for the translation as such but also for its style and the 'revolution' it commenced. Delisle \&

\footnotetext{
12 Cf. Berger (1884) for a catalogue of these translations.

13 Cf. Berger (1884) and Rector (2009, (2010) for information on Psalter translations into romanz.
} 
Woodsworth (1995: 33) state that "Tyndale translated into the language people spoke, not the way the scholars wrote", by which means, as Howard (1994: 16) quoted by them contends, "[h]e introduced the revolutionary notion that the common English spoken by the man in the street is as good as Latin or French or any other 'learned' language for expressing profound or poetic thought".

Inappropriate as English might have seemed to be still in the 14th century, it nevertheless served Richard Rolle, and for that matter the translators of the other Psalters mentioned above, as a vehicle for rendition. Rolle determined to use "na straunge ynglis, bot lyghtest and comonest" (Bramley 1884: 4) for the benefit of those "that knawes noght latyn" (Bramley 1884: 4), which would agree with Partridge's (1973: 21) statement given in the Introduction. Note, however, that it is not synonymous with the claim that Rolle resolved to adhere to native vocabulary.

As regards the linguistic landscape, Middle English was the period in which the loanwords of Scandinavian origin, whose number cannot be given exactly, began to be attested in writing (Björkman 1900, Burnley 1992, Kastovsky 1992). ${ }^{14}$ The greatest number of items with this etymology appear in the texts originating in the north (Freeborn 1998: 156, Burnley 1992: 421-422, Ringe \& Eska 2013: 74), ${ }^{15}$ which is worth emphasising as RRP is the only rendition among these juxtaposed in the research to originate in this part of England. The Middle English period was also the time when English, in addition to Scandinavian 'acquisitions', absorbed ca. 10,000 lexical items of Romance provenance (van Gelderen 2006: 99). Similarly to borrowings from ON, also Romance loanwords exhibit a geographical distribution pattern. Contrary to borrowings with ON etymology, however, whose greatest concentration, as mentioned above, is to be found in the texts of northern origin, the highest proportion of Romance-derived vocabulary appears in southern works (Burnley 1992: 431, Freeborn 1998: 156). As explained by Rothwell (1983: 258), this had to do with the "distance from the centre of government and culture (using

14 A comprehensive study of loanwords from Old Norse and Anglo-Norse language contact is offered by Townend (2002). The author recommends that the identification of Scandinavian borrowings in the Old and Middle English periods be performed on the basis of agentivity, as postulated by van Coetsem (1988). In particular, it is proposed that source language agentivity versus recipient language agentivity result in the presence in the target language of impositions and borrowings respectively. The difference between the two manifests itself in the phonological shape of the loanwords as each agent strives to preserve stable domains of their language.

15 In this context, see also Dance (2003), who discusses 'Old Norse-derived words' in detail for the South-West Midland texts and postulates that their presence in the works from this area can most likely be explained by the interdialectal transference of words from the North, "where they were originally loaned, and from which movement began to occur probably no later than the tenth century for the most part" (Dance 2003: 328). 
the phrase in its broadest sense)", i.e., London, the prime point of junction between English and French (Rey, Duval and Siouffi 2011: 305). It is certainly impossible to tell if the words still had some degree of the 'foreign aftertaste', yet the fact remains that the vocabularies of the three languages in use at the time, (Middle) English, (Anglo-)French and (Anglo-)Latin, were intermingled to an extent which often precludes assigning them to a language of origin:

\footnotetext{
"To use the term 'borrowing' for this very large-scale process of immersion and absorption that must have extended nation-wide over many decades is to belittle one of the most crucial movements in the history of the English language . [...] In England in the later fourteenth century the lexes of English and French were so imbricated as to be distinguishable only at the cost of some artificiality" (Rothwell 2000: 51)
}

The vocabularies in question were inseparable in the minds of the speakers with the lexical items 'borrowed' so easily as to create what may be considered a common lexicon shared by the languages or even a hybrid language using elements of the three: ${ }^{16}$

"This language uses English, French and Latin terminology in various combinations and relies on the reader's recognition of the semantic content of the words used and a straightforward word-order rather than any established pattern of syntax to convey its meaning" (Rothwell 2001: 18)

Beyond any doubt, it would hardly have been conceivable for such linguistic circumstances to leave no trace upon the etymological make-up of the Psalter translations analysed in this study. Whether they rendered the language of the translation(s) less proper (Partridge 1973: 21) remains to be seen.

\section{Methodology}

As explained in the Introduction, the paper analyses the nominal layer of the first fifty Psalms of Richard Rolle's Psalter in relation to the remaining three texts: the two Wycliffite renditions and the Middle English Glossed Prose Psalter, or rather its two manuscripts, all as presented in Charzyńska-Wójcik (2013). The starting point of the research was the Latin text of the Psalter, since all the texts are translations from the Latin Vulgate, and more precisely four versions of the Gallicanum as provided in Charzyńska-Wójcik (2013), one of them being the Latin text of Richard Rolle's Psalter.

16 Such a stance is also expressed by Meecham-Jones (2011), Trotter $(2003,2011)$, and Wright (2011). The extent of this phenomenon is well illustrated by the fact that in the medieval mixed-language business writings analysed by Wright $(2000,2011)$ abbreviation and suspension marks allowed the text to be decoded in any of the three languages without losing its semantic content. 
The process of the database preparation followed the course specified here. Having extracted all the nouns from the Latin source text(s) ${ }^{17}$ (2865 items), I annotated each with the Psalm and verse numbers and grouped all the occurrences of a single Latin lemma under one headword, providing each occurrence with the corresponding lexical item from the English renditions, together with the etymological information from the Middle English Dictionary (the MED) and the Oxford English Dictionary (the OED). ${ }^{18}$ The following step was to exclude from the data all the occurrences of Latin nouns whose corresponding lexical items were not labelled nouns in the relevant dictionaries or were whole phrases rather than nouns only. This procedure considerably reduced the number of analysed items to 2,322 occurrences for each of the texts. The database obtained in this manner was then analysed from the perspective of etymology in search of the evidence which may (in)validate the claim about Rolle's adherence to native items. The results gathered in the course of the research are presented in the following section.

At this point it remains only to expound upon the criteria I adopted for the purpose of assigning particular items to given etymological groupings. As stated above, the etymological data I based the study on were supplied by the MED and the OED, with the former treated as the leading source in the cases where the information presented by the two dictionaries diverges. The priority given to the MED in such instances stems from its exclusive focus on the relevant period in the history of the English language. ${ }^{19}$

On the basis of the data gathered from these dictionaries, I established two major etymological categories - one groups native nouns and the other those of foreign provenance. Although the notion native may seem to be quite straightforward, it comprises in fact three subcategories: nouns of purely Old English (OE) origin, those with mixed OE-ON (Old Norse) etymology and those of OERomance provenance. The definition of native adopted in the study has been so broadened based on the premise that the early loans (which functioned in the English lexicon already in the OE period alongside the truly native items and underwent the same morpho-phonological processes) may indeed be regarded as native in the language. Such a classification applies, however, only to those among the analysed items that are assigned such mixed, OE-ON or OE-Romance, origin by the relevant dictionaries, while the items borrowed in the OE period which do not

17 For the purposes of the research a 'noun' is an item labelled as such in the relevant dictionaries used in the study: for Latin it is WORDS Latin-to-English \& English-to-Latin Dictionary by William Whitaker, whereas for the data from English these are the Middle English Dictionary and The Oxford English Dictionary. All proper nouns, however, are excluded from the study. The complete database provides also the dates of the items' first recorded usages in the relevant meanings.

19 For a detailed account of the rationale behind this decision, see Lis (2014). 
receive this classification represent the other major category, grouping the items of foreign provenance. The category consists essentially of two types of items: borrowings from $\mathrm{ON}$ and loanwords with Romance ${ }^{20}$ etymology. As noted above, they range from those borrowed already in the OE period to fresh ME loanwords $^{21}$ but are not classified as representing mixed origin by the relevant dictionaries. Thus an item was assigned to the category of:

(i) native nouns when it was labelled as such by the two dictionaries or when one or both of them assigned it a mixed OE-ON or OERomance etymology,

(ii) Romance nouns when the dictionaries stated it came from Latin and/or (any form of) French,

(iii) ON nouns when its provenance was presented as such in the dictionaries.

The data categorised according to the above criteria are presented below.

\section{The data}

The section is divided into two subsections, with Section 5.1, comparing the etymological make-up of the four Psalters as regards native vs. foreign opposition. In contrast, Section 5.2 focuses on the loanwords, presenting the ratio between borrowings from different languages of origin in each of the texts.

\subsection{Native vs. foreign}

As stated in Section 4, the number of lexical items analysed for each of the texts equals 2,322 , which should present a trustworthy picture of the etymological

20 For reasons pertaining to the linguistic situation in medieval England mentioned in Section 3 and due to the ensuing lexicographical issues, I do not differentiate between items of Latin, French, Anglo-French/Anglo-Norman and mixed Latin-(Anglo-)French origin. For a detailed account of these, see Lis (2014).

21

The term loanword is used in this paper as a synonym to (lexical) borrowing and defined after Haspelmath (2008: 46) as a word "that is transferred from a donor language to a recipient language". Such a definition allows one to dispense with drawing a division between a foreign word ("non-integrated word from a foreign language", as cited in Grzega 2003: 26, after Betz 1949 and Duckworth 1977) and a loanword ("integrated word from a foreign language" Grzega 2003: 27, after Betz 1949 and Duckworth 1977). It is important to emphasize this broad understanding of the term since, as postulated by Grzega (2003: 27), "the criteria on which the division should be based (linguistic as opposed to sociolinguistic, or both combined) are not unanimously agreed upon by linguists and even within one strictly defined framework certain items seem to pose difficulties" (Lis 2014: 131). Grzega (2003: 28), who works in a cognitive onomasiological approach, considers the distinction between a loanword and a foreign word to be "of minor importance". 
K. Lis

make-up of the nominal layer of the first fifty Psalms in the relevant translations. The numerical and percentage data are given below in table 1 and chart 1 .

The table provides the number of native and foreign items, and differentiates between the borrowings which appear in one of the Psalters where all other renditions employ native nouns and those which in the parallel verses of the remaining translations find also items with foreign provenance, be they the same or different. Thus, for instance in the case of RRP out of the 2,322 nouns $1,837(79,11 \%)$ are native in origin, whereas the remaining 485 items are loanwords. In 453 cases (out of 485) RRP uses exactly the same item which is employed in the parallel verse in one or more of the remaining texts analysed in this study.

Table 1: Native vs. foreign items

\begin{tabular}{cccccc}
\hline & NATIVE & $\begin{array}{c}\text { FOREIGN } \\
\text { where } \\
\text { other texts } \\
\text { use native } \\
\text { items }\end{array}$ & $\begin{array}{c}\text { Fore one or } \\
\text { more texts } \\
\text { also use } \\
\text { loanwords }\end{array}$ & SUM & SUM \\
RRP & 1,837 & 32 & 453 & 485 & 2,322 \\
& $(79.11 \%)$ & $(1.38 \%)$ & $(19.51 \%)$ & $(20.89 \%)$ & \\
MEGPP L & 1,788 & 30 & 504 & 534 & 2,322 \\
& $(77 \%)$ & $(1.29 \%)$ & $(21.71 \%)$ & $(23 \%)$ & \\
MEGPP D & 1,820 & 3 & 499 & 502 & 2,322 \\
& $(78.38 \%)$ & $(0.13 \%)$ & $(21.5 \%)$ & $(21.62 \%)$ & \\
EV & 1,783 & 14 & 525 & 539 & 2,322 \\
& $(76.79 \%)$ & $(0.6 \%)$ & $(22.61 \%)$ & $(23.21 \%)$ & \\
LV & 1,791 & 11 & 520 & 531 & 2,322 \\
\hline
\end{tabular}




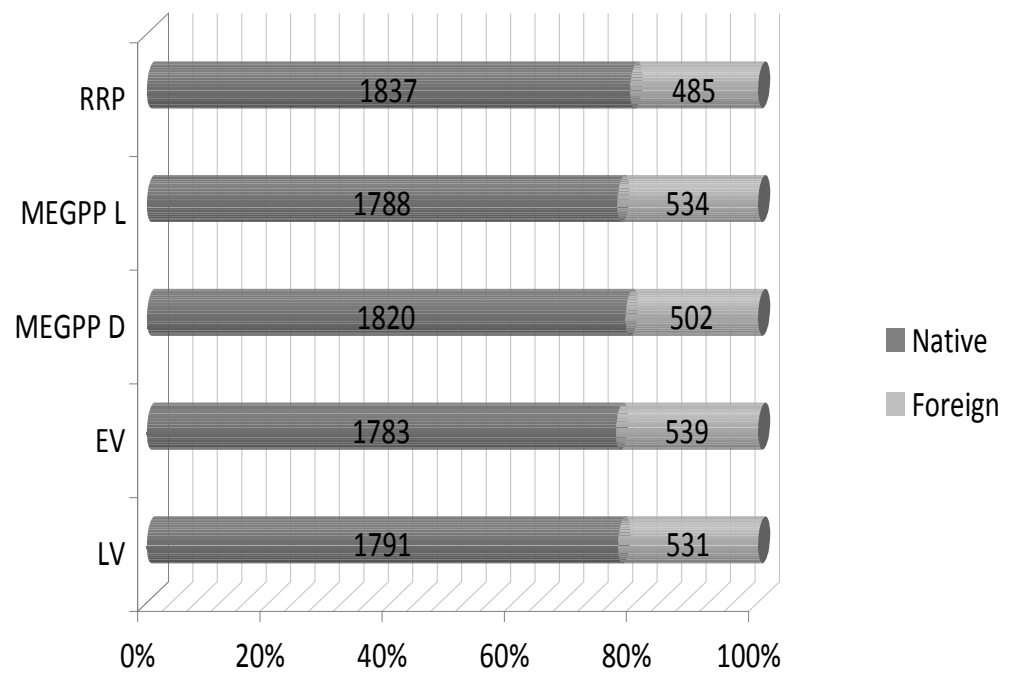

Chart 1: Native vs. foreign items

What transpires from the data presented above is that, although RRP indeed employs the greatest number $(1,837)$ of native nouns (at least in the first fifty Psalms) of all the Psalters analysed here, the numerical and percentage divergences between all the texts do not appear to be great - they range from $76.79 \%$ to $79.11 \%$. Nevertheless, the discrepancies in the number of borrowings as opposed to the number of native items prove to be statistically significant. An analysis by means of Cochran's Q test run on all the Psalters yielded Cochran's Q equal 29.166 for 4 degrees of freedom at 0.05 significance level, the P-value being lower than $0.001 .^{22}$ The value of Cochran's Q after the exclusion of RRP from the analysis decreases to 11.650 (3 degrees of freedom, 0.05 significance level, P-value equal to 0.009), yet it is only when both RRP and MEGPP D are excluded from the calculations that the differences in the number of native as opposed to foreign items between the Psalters, i.e. EV, LV and MEGPP L, are no longer statistically significant (Cochran's Q equals 0.419 with 2 degrees of freedom and P-value of 0.811). These findings engender a question about the statistical significance of the numerical discrepancy between RRP and MEGPP D, since both Psalters differ from EV, LV and MEGPP L, forming as if a homogenous group in this respect, in the lower number of borrowings employed. To establish this and the analogous relations between the remaining pairs of

22 All the calculations whose results are presented here were performed using IBM SPSS Statistics. 
Psalters, I ran pairwise comparisons using the McNemar test, since in this case I compared only two texts at a time, with Bonferroni correction to address the problem of multiple comparisons (Bonferroni correct $\mathrm{p}$ equals 0.005 in this case due to the fact that 10 different tests needed to be performed). The findings are presented in table 2 below, with the statistically significant results in bold type.

Table 2: McNemar test: Native vs. foreign items

\begin{tabular}{llc}
\hline $\mathrm{N}^{\mathrm{o}}$ & PSALTERS & MCNEMAR TEST \\
\hline 1 & RRP-MEGPP D & 0.213 \\
2 & RRP-MEGPP L & $\mathbf{0 . 0 0 0}$ \\
3 & RRP-EV & $\mathbf{0 . 0 0 0}$ \\
4 & RRP-LV & $\mathbf{0 . 0 0 0}$ \\
5 & MEGPP D-MEGPP L & $\mathbf{0 . 0 0 0}$ \\
6 & MEGPP D-EV & $\mathbf{0 . 0 0 5}$ \\
7 & MEGPP D-LV & 0.030 \\
8 & MEGPP L-EV & 0.777 \\
9 & MEGPP L-LV & 0.886 \\
10 & EV-LV & 0.422 \\
\hline
\end{tabular}

In accordance with the results of Cochran's $Q$ test, the differences in the number of loanwords versus native items between MEGPP L, EV and LV are not statistically significant under the McNemar test (8-10). Neither is there a statistically significant difference between MEGPP D and RRP in this respect (1). However, it might be of interest to note that the discrepancies in the number of borrowings and nouns of native origin between MEGPP D and LV are not statistically significant either (7), despite the fact that the number of loanwords present in LV (531) is close to the relevant numbers for MEGPP (534) and EV (539). Thus, the differences between the data obtained from these four Psalters, although admittedly significant in the light of the statistical analysis, appear not to be substantial.

Therefore, on the basis of these findings, albeit indicating statistically significant differences in the number of loanwords as opposed to native items between the texts, with RRP being the primary source of the divergence, one cannot speak of Rolle's adherence to native vocabulary to an extent that would be considerably greater than that of the translators of other texts since the differences between the figures for each of the Psalters seem to be too small. Moreover, as mentioned above, one of the Psalters (LV) does not exhibit statistically significant differences, regardless of whether juxtaposed with MEGPP D or when compared with MEGPP L and EV, i.e. texts representing as if separate groups with respect to the borrowings-native items ratio. 
Another fact that should not be ignored is that RRP is the very text to employ the highest number of borrowings in the contexts where all the remaining Psalters opt for native items, i.e. in the contexts where perfectly adequate native terms do exist.

\subsection{Etymological make-up of the group of borrowings}

Having discussed the ratio of borrowings to native items in the relevant Psalters, I will now concentrate on the percentage participation of nouns with different etymologies in the total number of nominal loanwords attested in the first fifty Psalms in these texts. The relevant data are provided in table 3 and chart 2.

Table 3: Etymological make-up of the group of borrowings

\begin{tabular}{|c|c|c|c|c|c|}
\hline & & $\begin{array}{c}\text { where } \\
\text { other } \\
\text { texts use } \\
\text { native } \\
\text { items }\end{array}$ & $\begin{array}{c}\text { where one } \\
\text { or more } \\
\text { texts also } \\
\text { use loan- } \\
\text { words }\end{array}$ & SUM & TOTAL \\
\hline \multirow{4}{*}{ RRP } & & 6 & 427 & 433 & \multirow{4}{*}{485} \\
\hline & RUMANCE & $(1.39 \%)$ & $(98.61 \%)$ & $89.28 \%)$ & \\
\hline & $\mathrm{ON}$ & $26(52 \%)$ & $\begin{array}{c}24 \\
(48 \%)\end{array}$ & $\begin{array}{c}50 \\
(10.31 \%)\end{array}$ & \\
\hline & $\mathrm{MLG}^{24}$ & $\begin{array}{c}0 \\
(0 \%)\end{array}$ & $\begin{array}{c}2 \\
(100 \%)\end{array}$ & $\begin{array}{c}2 \\
(0.41 \%)\end{array}$ & \\
\hline \multirow{2}{*}{ MEGPP L } & ROMANCE & $\begin{array}{c}30 \\
(5.7 \%)\end{array}$ & $\begin{array}{c}496 \\
(94.3 \%)\end{array}$ & $\begin{array}{c}526 \\
(98.5 \%)\end{array}$ & \multirow{2}{*}{534} \\
\hline & ON & $0(0 \%)$ & $\begin{array}{c}8 \\
(100 \%)\end{array}$ & $\begin{array}{c}8 \\
(1.5 \%)\end{array}$ & \\
\hline \multirow{2}{*}{ MEGPP D } & ROMANCE & $\begin{array}{c}3 \\
(0.61 \%)\end{array}$ & $\begin{array}{c}488 \\
(99.39 \%)\end{array}$ & $\begin{array}{c}491 \\
(97.81 \%)\end{array}$ & \multirow{2}{*}{502} \\
\hline & ON & $\begin{array}{c}0 \\
(0 \%)\end{array}$ & $\begin{array}{c}11 \\
(100 \%)\end{array}$ & $\begin{array}{c}11 \\
(2.19 \%)\end{array}$ & \\
\hline \multirow{2}{*}{ EV } & ROMANCE & $\begin{array}{c}14 \\
(2.64 \%)\end{array}$ & $\begin{array}{c}516 \\
(97.36 \%)\end{array}$ & $\begin{array}{c}530 \\
(98.33 \%)\end{array}$ & \multirow{2}{*}{539} \\
\hline & ON & $\begin{array}{c}0 \\
(0 \%)\end{array}$ & $\begin{array}{c}9 \\
(100 \%)\end{array}$ & $\begin{array}{c}9 \\
(1.67 \%)\end{array}$ & \\
\hline
\end{tabular}




\begin{tabular}{cccccc}
\hline \multirow{3}{*}{ ROMANCE } & 11 & 510 & 521 & \\
& & $(2.11 \%)$ & $(97.89 \%)$ & $(98.12 \%)$ & 531 \\
& ON & 0 & 10 & 10 & \\
& & $(0 \%)$ & $(100 \%)$ & $(1.88 \%)$ & \\
\hline
\end{tabular}

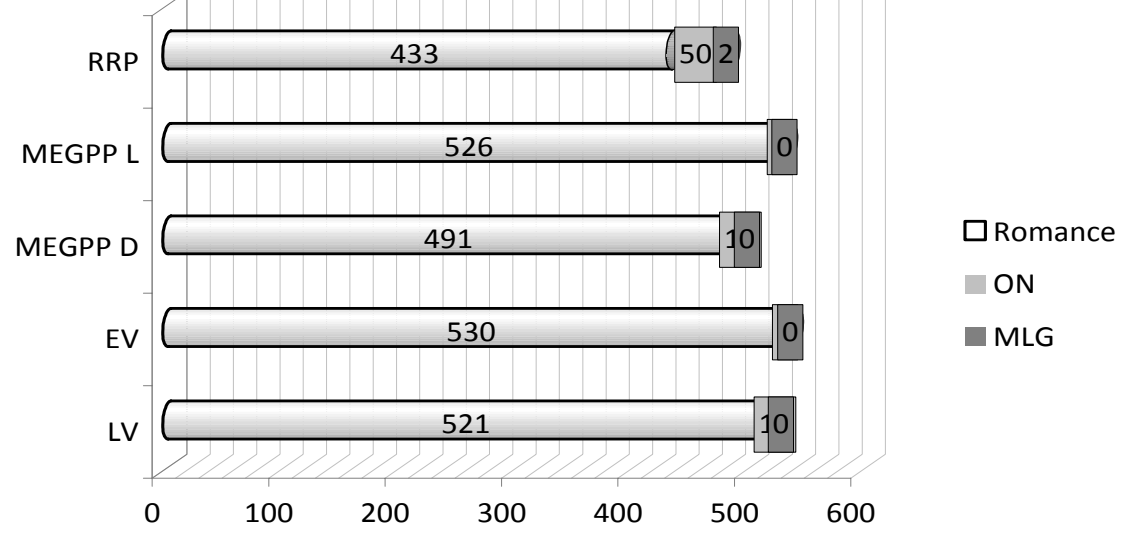

Chart 2: Etymological make-up of the group of borrowings

The picture emerging upon the analysis of these data is not as uniform as the one evoked by the data from table 1 . Set against the background of all the remaining Psalters, RRP seems to be unique in the frequency with which it employs nouns of ON origin: within the body of the first fifty Psalms there are 50 such items $-10.31 \%$ of all the borrowings in this Psalter - and more than $50 \%$ (26 items) of them appear in the contexts where the remaining texts employ native nouns. This divergence between the texts appears to be telling despite the fact that the number of such borrowings among the analysed items, when juxtaposed with the number of Romance loanwords, does not appear to be substantial in any of the texts, ranging from 8 to 50 borrowings.

In order to verify if the numerical differences in the distribution of loanwords with different etymologies (Romance and then $\mathrm{ON}$ ) with respect to the remaining nominal items, be they native or borrowed, between the texts are statistically significant, I conducted further Cochran's Q tests. These, when ran on all the Psalters, indicate that the discrepancies in the number of borrowings, both Romance and $\mathrm{ON}$, are highly significant at 0.05 significance level for 4 degrees of freedom (cf. table 4; as in Section 5.1, also here I emboldened the statistically significant results). Cochran's Q equals 88.059 for Romance borrowings and 125.448 for ON loanwords. In the case of the loanwords from Romance languages, the differences are still significant, though considerably less so, after the exclusion of RRP from 
the analysis (12.758) but cease to be so when only MEGPP, EV and LV are juxtaposed. The pairwise comparisons (by means of the McNemar test) between all the Psalters are provided in table 5 and, as predicted by the results yielded by Cochran's Q test, do not indicate statistically significant differences between MEGPP L, EV and LV in this respect.

However, as far as ON loanwords are concerned, the differences are statistically significant, and highly so, only when RRP is taken into consideration. Thus, there are no statistically significant discrepancies in the number of nouns of ON origin employed between the remaining four ME Psalters, which renders all the tests not involving RRP redundant, but I provide the results of these for the sake of consistency.

Table 4: Cochran's Q test: Romance vs. other nouns and ON vs. other nouns comparison between the Psalters

\begin{tabular}{lcccccc}
\hline & \multicolumn{3}{c}{ ROMANCE } & & ON & \\
& $\begin{array}{c}\text { Cochran's } \\
\text { Q }\end{array}$ & $\begin{array}{c}\text { degrees } \\
\text { of } \\
\text { freedom }\end{array}$ & $\begin{array}{c}\text { P- } \\
\text { value }\end{array}$ & $\begin{array}{c}\text { Cochran's } \\
\text { Q }\end{array}$ & $\begin{array}{c}\text { degrees } \\
\text { of } \\
\text { freedom }\end{array}$ & $\begin{array}{c}\text { P- } \\
\text { value }\end{array}$ \\
\hline $\begin{array}{l}\text { MEGPP } \\
\text { L-MEGPP }\end{array}$ & $\mathbf{8 8 . 0 5 9}$ & $\mathbf{4}$ & $\mathbf{0 . 0 0 0}$ & $\mathbf{1 2 5 . 4 4 8}$ & $\mathbf{4}$ & $\mathbf{0 . 0 0 0}$ \\
$\begin{array}{l}\text { D-RRP- } \\
\text { EV-LV }\end{array}$ & & & & & & \\
$\begin{array}{l}\text { MEGPP } \\
\text { L- MEGPP }\end{array}$ & $\mathbf{1 2 . 7 5 8}$ & $\mathbf{3}$ & $\mathbf{0 . 0 0 5}$ & 1.765 & 3 & 0.623 \\
$\begin{array}{l}\text { D-EV-LV } \\
\text { MEGPP }\end{array}$ & 0.508 & 2 & 0.776 & 1.000 & 2 & 0.607 \\
L-EV-LV & 0 & & & & & \\
\hline
\end{tabular}

Table 5: McNemar test: Romance borrowings vs. other nouns and ON borrowings vs. other nouns ${ }^{25}$

\begin{tabular}{llcc}
\hline $\mathrm{N}^{\mathrm{o}}$ & PSALTERS & ROMANCE - & ON - MCNEMAR \\
& & MCNEMAR TEST & TEST \\
\hline 1 & RRP-MEGPP D & $\mathbf{0 . 0 0 0}$ & $\mathbf{0 . 0 0 0}$ \\
2 & RRP-MEGPP L & $\mathbf{0 . 0 0 0}$ & $\mathbf{0 . 0 0 0}$ \\
3 & RRP-EV & $\mathbf{0 . 0 0 0}$ & $\mathbf{0 . 0 0 0}$ \\
4 & RRP-LV & $\mathbf{0 . 0 0 0}$ & $\mathbf{0 . 0 0 0}$ \\
5 & MEGPP D- & $\mathbf{0 . 0 0 0}$ & 0.375 \\
& MEGPP L & & \\
6 & MEGPP D-EV & $\mathbf{0 . 0 0 4}$ & 0.727 \\
\hline
\end{tabular}

25 Also here Bonferroni correction was applied. 


\begin{tabular}{llll}
\hline 7 & MEGPP D-LV & 0.029 & 1.000 \\
8 & MEGPP L-EV & 0.834 & 1.000 \\
9 & MEGPP L-LV & 0.777 & 0.687 \\
10 & EV-LV & 0.362 & 1.000 \\
\hline
\end{tabular}

A closer analysis of the data given in table 5 allows one to notice certain convergences and divergences in the data between the texts, shedding more light on the findings presented in Section 5.1, which, when glimpsed from the distance necessitated by the calculations performed there, could lead one to some erroneous conclusions. First and foremost, the differences between RRP and MEGPP D (1) in the number of both Romance and ON loanwords are statistically significant. This is of immense importance in the light of the fact that when treated jointly, the divergence in the number borrowings between these two was not significant from the point of view of statistics ( 1 in table 2$)$. Therefore, although admittedly making more judicious use of loanwords than MEGPP, EV and LV, MEGPP D differs from RRP with respect to the type of borrowings it does employ.

It is interesting to notice that also in the case of the juxtaposition of Romance borrowings with all the remaining lexical items analysed in the study, the divergence between MEGPP D and LV is not statistically significant, although it is so with MEGPP L and EV. This finding, once again, leads one to conclude that the numerical differences in the number of Romance loanwords between MEGPP D and other Psalters excluding RRP are not too considerable, despite the fact that they prove to be statistically significant.

Such results confirm that the differences in the number of items with $\mathrm{ON}$ and Romance etymology employed in the texts cannot be due to chance. The findings neatly corroborate the generally observed tendency for words of Scandinavian origin to appear more frequently in the texts of northern provenance, such as RRP, and those with Romance etymology to be present in greater numbers in southern writings, although the idiosyncrasy represented by MEGPP D cannot be overlooked. Interestingly, the fact that this tendency finds a reflection in the results obtained in this study is itself also the evidence that the data, in respect of both their type and amount, used in the research are reliable.

It might be of interest to note that RRP is also exceptional in its use of the only word among all the analysed data to be of different than Romance or ON provenance. The item(s) in question are two instances of a MLG-derived noun nēr(e 'a kidney' to render Latin ren, renis 'kidney(s)'. 


\section{Conclusions}

The data presented in Section 5 seem to refute Partridge's (1973: 21) claim pertaining to Rolle's adherence to native vocabulary. Despite the fact that variation in the participation of native nouns in the texts between the Psalters is statistically significant, the divergences are not too considerable. It needs to be emphasised at this point that one of the texts - the Dublin manuscript of MEGPP - does not exhibit statistically significant differences in this respect either when juxtaposed with RRP or in comparison with LV. This is telling since the latter together with EV and MEGPP L form a group of texts representing no statistically significant divergences whatsoever as far as the etymological aspect of their noun choices is concerned. Undoubtedly, RRP is the most exceptional of the analysed texts vocabulary-wise as both the number of Romance and ON borrowings set it apart from the other renditions. As stated in Section 5.1 , the latter observation goes hand in hand with the tendency of such items to appear in the texts originating in northern areas of England (Freeborn 1998: 156, Burnley 1992: 421-422, Ringe \& Eska 2013: 74). Most importantly, RRP is also the very Psalter to use the greatest number of borrowings in the contexts where all the remaining texts opt for native items.

The results of this study inevitably engender the question about the source of Partridge's (1973:21) claim which I take the liberty to quote again, more extensively this time:

\footnotetext{
"Rolle adhered with fidelity to the Latin original, using the simplest and most proper English wherever possible, except when his native language failed him, and he was compelled to latinize. When he added or paraphrased, it was because he found it necessary to expound certain meanings, as given to him by his learned authority. In this way he safeguarded himself against any accusation of varying his text"
}

What comes to mind on reading the excerpt is that such a statement may well have been induced, at least partially, by an over-interpretation of the Prologue to the Psalter, where Rolle indeed speaks of striving to use the 'lyghtest and comonest' English but does not equate it with the preference for native vocabulary:

"In this werke .i. seke na straunge ynglis, bot lyghtest and comonest. and swilk that is mast lyke til the latyn. swa that thai that knawes noght latyn. by the ynglis may com til mony latyn wordis. In the translacioun i. folow the lettere als mykyll as .i. may. And thare. i. fynd na propire ynglis. i. folow the wit of the worde, swa that thai that sall red it thaim thare noght dred errynge. In expounynge. i. fologh haly doctours. for it may come in some enuyous man hand that knawes noght what he sould say, that will say that. i. wist noght what. i. sayd. and swa doe harme til hym. and til othere. if he dispise the werke that is profytabile for hym and othere"26 (Bramley 1884: 4-5) 
The source of the assertion about Rolle's adherence to the vocabulary of OE origin might therefore lie in the different perception of what "the simplest and most proper English" (Partridge 1973: 21) is. This, in turn, inevitably stems from the differences of the linguistic and cultural environments in which the statements were pronounced. As argued in Section 3, the boundaries between the languages in use in 14th-century England were vague, if, in some contexts, present at all. The extent of vocabulary mixing is still more evident when set against the backdrop of the contemporary conservative approach to biblical translations (Section 3) and the historical and cultural context in which the texts were compiled, as presented, to the extent relevant for the purposes of the paper, in Section 2. In medieval multilingual England 'simple' and 'proper' English was not the language dispensing with borrowings as these were as much part of the lexicon in this multicultural society as vocabulary of strictly native origin. In other words, medieval England was not the world in which such forms of linguistic purism would find fertile ground to flourish.

\section{REFERENCES}

\section{PRIMARY SOURCES}

Allen, Rosamund S. 1988. Richard Rolle. The English writings (Classics of Western Spirituality). New York, NY: Paulist Press.

Black, Robert R. \& Raymond St-Jacques (eds.). 2012. The Middle English Glossed Prose Psalter. 2. vols. (Middle English Texts 45-46). Heidelberg: Winter.

Bramley, Henry R. (ed.). 1884. The Psalter, or Psalms of David and certain canticles, with a translation and exposition in English by Richard Rolle of Hampole. Oxford: Clarendon Press.

Bülbring, Karl D. (ed.). 1891. The earliest complete English prose Psalter, together with eleven canticles and a translation of the Athanasian creed (Early English Text Society Original Series 97). London: Kegan Paul, Trench, Trübner and co.

Carney, Ellen A. (ed.). 1980. Richard Rolle's English Psalter, Psalms 91-105: An edition with an introductory essay on Rolle's style. Unpublished Ph.D. thesis: Fordham University.

EV and LV $=$ Forshall, Josiah \& Frederic Madden (eds.).

Forshall, Josiah and Frederic Madden (eds.). 1850. The Holy Bible, containing the Old and New Testaments, with the Apocryphal Books, in the earliest English versions made from the Latin Vulgate by John Wycliffe and his followers. Oxford: Oxford University Press.

Jerome, Eusebius Sophronius. [395] 1997. On the best kind of translator. Letter 57 to Pommachius. Translated by Paul Caroll. In Douglas Robinson (ed.), Western translation theory: From Herodotus to Nietzsche, 22-30. Manchester: St. Jerome.

cate the places where the original abbreviation and suspension marks employed in the manuscripts were expanded. 
Kurath, Hans, Sherman M. Kuhn, John Reidy, Robert E. Lewis et al. (eds.). 1952-2001. Middle English Dictionary. Ann Arbor, MI: University of Michigan Press. http://quod.lib.umich.edu/m/med/.

MED = Kurath, Hans, Sherman M. Kuhn, John Reidy, Robert E. Lewis et al. (eds.).

MEGPP = Bülbring, Karl Daniel (ed.).

OED $=$ Simpson, John and Edmund Weiner (eds.).

Paues, Anna C. (ed.) 1902. A fourteenth century English Biblical version, consisting of a prologue and parts of the New Testament edited from the manuscripts together with some introductory chapters on Middle English Biblical versions (prose-translations). Cambridge: Cambridge University Press.

Pollard, Alfred W. (ed.). 1911. Records of the English Bible: The documents relating to the translation and publication of the Bible in English, 1525-1611. London: Henry Frowde, Oxford University Press.

RRP $=$ Bramley, Henry R. (ed.).

Simpson, John \& Edmund Weiner. (eds.). 1989. Oxford English Dictionary (2nd edn). Oxford: Clarendon Press.

Whitaker, William. WORDS: Latin-to-English \& English-to-Latin dictionary. http://ablemedia. com/ctcweb/showcase/wordsonline.html.

\section{SECONDARY SOURCES}

Alford, John A. 1995. Rolle's "English Psalter" and "Lectio Divina". Bulletin of the John Rylands Library 77(3). 47-59.

Berger, Samuel. 1884. La Bible française au Moyen Age. Étude sur les plus anciennes versions de la Bible écrites en prose de langue d'oül. Paris: Imprimerie Nationale.

Betz, Werner. 1949. Deutsch und Lateinisch: Die Lehnbildungen der althochdeutschen Benediktinerregel. Bonn: Bouvier.

Björkman, Erik. 1900. Scandinavian loan-words in Middle English. Part I (Studien zur Englischen Philologie 7). Halle: Niemeyer.

Bobrick, Benson. 2001. The making of the English Bible. London: Weidenfeld \& Nicolson.

Burnley, David. 1992. Lexis and semantics. In Norman Blake (ed.), The Cambridge history of the English language. Volume II: 1066-1476. 409-499. Cambridge: Cambridge University Press.

Charzyńska-Wójcik, Magdalena. 2013. Text and context in Jerome's Psalters: Prose translations into Old, Middle and Early Modern English. Lublin: Wydawnictwo KUL.

Charzyńska-Wójcik, Magdalena. forthcoming. Going Dutch on the Scottish borders ... of the Psalter. In Aniela Korzeniowska and Izabela Szymańska (eds.). Scottish culture Dialogue and self-expression. Warszawa: Wydawnictwo Naukowe Semper.

Coetsem, Frans van. 1988. Loan phonology and the two transfer types in language contact (Publications in Language Sciences 27). Dordrecht: Foris.

Condit, Blackford. 1882. The history of the English Bible, extending from the earliest Saxon translations to the present Anglo-American revision, with special reference to the Protestant religion and the English language. New York: A.S. Barnes.

Dance, Richard. 2003. Words derived from Old Norse in Early Middle English: Studies in the vocabulary of the South-West Midland texts (Medieval and Renaissance Texts and Studies 246). Tempe, AZ: Arizona Center for Medieval and Renaissance Studies. 
Daniell, David. 2003. The Bible in English. Its history and influence. New Haven, CT: Yale University Press.

Deanesly, Margaret. 1920. The Lollard Bible and other medieval Biblical versions. Cambridge: Cambridge University Press.

Delisle, Jean \& Judith Woodsworth (eds.). 1995. Translators through history (Benjamins Translation Library 13). Amsterdam and Philadelphia, PA: John Benjamins Publishing Company.

Duckworth, David. 1977. Zur terminologischen und systematischen Grundlage der Forschung auf dem Gebiet der englisch-deutschen Interferenz: Kritische Übersicht und neuer Vorschlag. In Herbert Kolb \& Hartmut Lauffer (eds.). Sprachliche Interferenz: Festschrift für Werner Betz zum 65. Geburtstag, 36-56. Tübingen: Niemeyer.

Everett, Dorothy. 1922. The Middle English prose psalter of Richard Rolle of Hampole. The Modern Language Review 17(3). 217-227.

Freeborn, Dennis. 1998. From Old English to Standard English: A course book in language variation across time (2nd. edn.). Basingstoke and London: Macmillan.

Gelderen, Elly van. 2006. A history of the English language. Amsterdam and Philadelphia, PA: John Benjamins Publishing Company.

Grzega, Joachim. 2003. Borrowing as a word-finding process in cognitive historical onomasiology. Onomasiology Online 4: 22-42.

Hargreaves, Henry. 1965. From Bede to Wyclif: Medieval English Bible translations. Bulletin of the John Rylands Library 48(1). 118-140.

Hargreaves, Henry. 1969. The Wycliffite versions. In Geoffrey William Hugo Lampe (ed.), The Cambridge history of the Bible. Volume 2: The West from the Fathers to the Reformation, 387-415. Cambridge: Cambridge University Press.

Haspelmath, Martin. 2008. Loanword typology: Steps toward a systematic cross-linguistic study of lexical borrowability. In Thomas Stolz, Dik Bakker \& Rosa Salas Palomo (eds.), Aspects of language contact: New theoretical, methodological and empirical findings with special focus on Romancisation processes (Empirical approaches to language typology 36), 43-62. Berlin: Mouton de Gruyter.

Howard, Phillip. 1994. Philip Howard Column: Tyndale's language of the common man is the bedrock of English literature today. The Times (April 29, 1994).

IBM Corporation. Released 2013. IBM SPSS Statistics for Windows, Version 22.0. Armonk: IBM Corporation.

Kastovsky, Dieter. 1992. Semantics and vocabulary. In Richard M. Hogg (ed.), The Cambridge history of the English language. Volume I: The beginnings to 1066, 290-408. Cambridge: Cambridge University Press.

Lis, Kinga. 2014. The latinity of the Wycliffite Psalters. In Magdalena Charzyńska-Wójcik, Jerzy Wójcik \& Anna Bloch-Rozmej (eds.), Language change: Faces and facets (Studies in Linguistics and Methodology 7), 129-171. Lublin: Wydawnictwo KUL.

Lis, Kinga. 2015. How to measure the French influence - lexical choices in a 14th-century English Psalter. Manuscript in preparation.

McArthur, Tom (ed.). 1992. The Oxford companion to the English language. Oxford, New York, NY: Oxford University Press.

Meecham-Jones, Simon. 2011. "Gadryng togedre of medecyne in the partye of cyrugie": Strategies of code-switching in the Middle English translations of Chauliac's Chirurgia Magna. In Herbert Schendl \& Laura Wright (eds.), Code-switching in Early English (Topics in English Linguistics 76), 253-280. Berlin: Mouton de Gruyter. 
Norton, David. 2000. A history of the English Bible as literature. Cambridge: Cambridge University Press.

Partridge, Astley C. 1973. English Biblical translation. London: André Deutsch.

Poleg, Eyal \& Laura Light. 2013. Introduction. In Eyal Poleg \& Laura Light (eds.), Form and function in the late medieval Bible (Library of the Written Word 27), 1-7. Leiden: Brill.

Rector, Geoff. 2009. An illustrious vernacular: The Psalter en romanz in twelfth-century England. In Jocelyn Wogan-Browne et al. (eds.), Language and culture in medieval Britain. The French of England, c.1100-c.1500, 198-206. York: York Medieval Press.

Rector, Geoff. 2010. The Romanz Psalter in England and Northern France in the twelfth century: Production, mise-en-page, and circulation. Journal of the Early Book Society 13. 1-38.

Reuter, Ole. 1938. A study of the French words in the "Earliest Complete English Prose Psalter" (Societas Scientiarum Fennica. Commentationes Humanarum Litterarum 9(4)). Helsingfors: Akademische Buchhandlung.

Rey, Alain, Frédéric Duval \& Gilles Siouffi. 2011. Mille ans de langue française: Histoire d'une passion. I. Des origines au français moderne. Paris: Perrin.

Riehle, Wolfgang. 2014. The secret within: Hermits, recluses, and spiritual outsiders in medieval England. Ithaca, NY: Cornell University Press.

Ringe, Donald \& Joseph F. Eska. 2013. Historical linguistics. Toward a twenty-first century reintegration. Cambridge and New York, NY: Cambridge University Press.

Rothwell, William. 1983. Language and government in Medieval England. Zeitschrift für französische Sprache und Literatur 93(3). 258-270.

Rothwell, William. 2000. Anglo-French and Middle English vocabulary in Femina Nova. Medium Aevum 69(1). 34-58.

Rothwell, William. 2001. The teaching and learning of French in later medieval England. Zeitschrift für französische Sprache und Literatur 111(1). 1-18.

Shepherd, Geoffrey. 1969. English versions of the Scriptures before Wyclif. In Geoffrey William Hugo Lampe (ed.), The Cambridge history of the Bible. Volume 2: The West from the Fathers to the Reformation, 362-387. Cambridge: Cambridge University Press.

St-Jacques, Raymond. 1989. Middle English Glossed Prose Psalter and its French source. In Jeanette Beer (ed.), Medieval translators and their craft (Studies in Medieval Culture 25), 135-154. Kalamazoo, MI: Medieval Institute Publications.

Townend, Matthew. 2002. Language and history in Viking Age England. Linguistic relations between speakers of Old Norse and Old English (Studies in the Early Middle Ages 6). Turnhout: Brepols.

Trotter, David. 2003. Oceano vox: You never know where a ship comes from. On multilingualism and language-mixing in medieval Britain. In Kurt Braunmüller \& Gisella Ferraresi (eds.), Aspects of multilingualism in European language history (Hamburg Studies on Multilingualism 2), 15-33. Amsterdam and Philadelphia, PA: John Benjamins Publishing Company.

Trotter, David. 2011. Death, taxes and property: Some code-switching evidence from Dover, Southampton, and York. In Herbert Schendl \& Laura Wright (eds.), Code-switching in Early English (Topics in English Linguistics 76), 155-189. Berlin: Mouton de Gruyter.

Wells, John Edwin. 1916. A manual of the writings in Middle English, 1050-1400. London: Oxford University Press and New Haven, CT: Yale University Press. 
Wright, Laura. 2000. Bills, accounts, inventories: Everyday trilingual activities in the business world of later medieval England. In David A. Trotter (ed.), Multilingualism in later medieval Britain, 149-156. Cambridge: D. S. Brewer.

Wright, Laura. 2011. On variation in medieval mixed-language business writing. In Herbert Schendl \& Laura Wright (eds.), Code-switching in Early English (Topics in English Linguistics 76), 191-218. Berlin: Mouton de Gruyter. 